\title{
Outback Oz: a study of one learner's journey of liberation with the help of a portable computer
}

\author{
Adrienne Sallay \\ University of Technology \\ Sydney \\ Australia
}

\begin{abstract}
This paper concerns a student achieving success with the aid of a portable computer. Robin, a 12 year old boy with learning difficulties, set off on a trip through Australia's Red Centre desert lands in July 1993. His aim was to complete a diary of his travels for a Year 7 geography assignment. His success in this endeavour, and his subsequent improvement in achievement in all areas, is documented in this paper.

A twenty minute video diary of the Outback $\mathrm{Oz}$ trip accompanies the paper, and will be shown at the conference. The video shows Robin using the computer to record events as they happened. The final assignment integrating the diary, database and spreadsheet with illustrations and photographs into a 200 page folder will also be available for viewing.
\end{abstract}

Main conference themes: learner centred learning

Educational areas:

Study topics:

Secondary keywords: case studies, motivation, portable computers, special needs 


\section{INTRODUCTION}

In New South Wales, the Geography curriculum for Year 7 (first year of secondary school) includes a study of the 'Red Centre' desert lands and the 'Top End' wetlands, both of which are in the Northern Territory. Robin, a Year Seven student, who had never completed a piece of prose, undertook to make a diary of the journey from Sydney to Darwin, via Broken Hill, and Alice Springs. As well as keeping a diary, he was to observe and list several geographic phenomena.

Accompanied by his father, the cameraperson, and a portable computer, Robin accomplished the seemingly daunting task of writing a detailed diary as he travelled the route. After returning home, he printed and collated his material, with photos and illustrations, into a final 200 page work. His assignment achieved the highest marks. His schoolwork since that achievement has made remarkable progress. One year later he was achieving at a higher level, even coming top of the class in the mid-year science examination. This paper describes Robin's case history in terms of context, subject, data collection, data analysis, and discussion.

\section{Context}

Often children with developmental delay, disability or learning difficulties have low self esteem which leads to underachievement. Self esteem, self image and self confidence are equated with self evaluation, that is, what persons think about themselves [1]. There has long been a body of thought which maintains that computers are especially valuable in helping handicapped students in developing self confidence, improving self concepts and achievement gains, in teaching coping and social skills and in learning to communicate. Research also shows that having access to computers for learning increases problem solving skills and positive attitudes.

Computers help develop self esteem by allowing the learner greater control of the learning situation, by creating a nonthreatening learning environment which is positive and secure, by providing intrinsic motivation, and, for writing tasks, by providing finished work which appears on an equal with good writers [2].

Studies support the premise that computers are beneficial for writing tasks. A two year study of fourth grade students in Massachusetts found that computers aided children's sense of ownership, of being in control and authoring the writing, and of their involvement in writing [3], while the Computer Education Unit in Sydney found that provision of a tool which makes the process of writing easier, and the process of editing easier, contributes to better quality writing [4]. 
In addition, the application of computer technology to the genre based approach to writing, e.g. diary writing, has huge possibilities for both social literacy and learner empowerment [5]. Students' writing is very legible and more acceptable, while the labour intensive work inherent in editing is removed and the final product is of better quality [6]. The page looks like everyone else's, no better, no worse, thus relieving the student with poor handwriting of any stigma attached to sub standard work.

When discussing achievement and success, success can be described as achieving at one's real potential. The significance of the relationship between self esteem and success is that with self confidence comes the ability to tackle new challenges, take risks, think and act creatively, thus extending one's potential [1]. There is adequate support in the literature for the power of computers helping students achieve success.

A program for fourth year secondary learning of disabled students combined special education, guidance and the utilisation of computers for word processing. Students from this program were applying for and being accepted into post secondary programs [7].

In another program for drop-out or high risk students incorporating the use of computers in both academic and vocational areas, where the program concentrated on building self esteem and self confidence, there was a $94 \%$ success rate for keeping students in school and successfully advancing to the next grade [8].

A program using computers to encourage self confidence among at-risk students in grades 4 to 7 showed positive results including increased academic achievement [9]. Another program for school retention which included traditional curriculum (health and drug education, drama, and personal diary writing) delivered by computers linked to a satellite showed positive results including increased academic achievement ([10].

Children with learning difficulties all have different needs. This paper describes a single case study of one boy's problems, and the momentous event which led to his first real academic success. The consequent raising of his self esteem had a ripple effect which led to success in other areas. However, it is important to note that this is only a single case study and that further research is needed in this area.

\section{Subject}

Robin was a boy with learning difficulties including lack of fine and gross motor skills, a high verbal skill and reading age, but poor writing skills. Written expression was frustrating for him because he had difficulty with sequencing which problem was rooted, neurologically, in his unresolved laterality [11]. The major manifestation of his learning difficulty in the classroom was an 
inability to formulate cursive letters when writing (Fig. 1). He thus was a reluctant writer who had rarely completed a writing task during his primary years and lacked practice in composing prose.

His maths was patchy and he had had several private coaching periods. His physical education skills, especially ball skills, were lacking. In the playground, his interaction skills with peers were also poor. In Year 6 he spent one whole term in the dunce's corner of the handball court (sent there by his peers) before he decided to spend playtime inside at the computer.



Fig. 1 Example of Robin's handwriting June 1993

Other consequences of this learning difficulty were a loss of self esteem and underachievement in all areas, from second grade when cursive handwriting became compulsory. There were, on average, 32 children in his class during 3 rd, 4th, 5th and 6 th grade. His class had 13 children characterized by the school as having learning problems. Because his reading age was high, 15 years and 6 months in December 1991 [12], he was offered no special tuition at school, as that tuition was reserved for children whose reading age was lower than average.

During the four primary years (1989-92) he had one spell of maths coaching, and three years of work outside school with a Steiner-trained educational psychologist. Activities offered him during this course included fine and gross motor practice, painting, knitting, left and right brain coordination exercises.

For the first half of Year 7 (1993) Robin was still achieving below his tested ability. Henry's tests found that his oral language skills were strong, his mental arithmetic skills and his visual and spatial skills were at the top of the average range, while his clerical skills were still poor. His examination results did not reflect these test results.

He had another spell of maths coaching. Although he did not have to worry about cursive script since his teachers did not now insist that he use it, writing was still a chore for him. He wrote as little as possible, and only under protest. Some teachers allowed him to do homework assignments on the computer, and one teacher allowed him to take notes in class on the computer. 
When the Outback Oz trip was undertaken, Robin's reading age was over 15 , his chronological age was 12 . He turned 13 during the journey. He was still writing reluctantly and underachieving in all areas.

\section{Data collection}

Data collection for this study was via observation using the video diary, and from other sources such as psychology tests and report cards.

The Geography assignment was set for the whole of Year 7 as an 'armchair travel' exercise. Students were given six months to research and write a journal describing the route from Adelaide to Darwin, with detours to Alice Springs and Kakadu. They were to include information about the landforms, the changing vegetation, any wildlife, changing weather conditions, farming and mining, towns and isolated settlements, and any special points of interest.

Using a computer, Robin wrote to the Tourist Information Centre in many of the towns asking for maps, information and illustrations. He was then lucky enough to have the opportunity to travel the route described during the July school holidays. He borrowed a portable computer on which to take notes, and set up files: a word processing file for the diary, a database file for the geographic features of the countryside and a spreadsheet file for expenses.

The portable computer allowed him the freedom to report information spontaneously. Robin's father accompanied him on the sixteen day bus tour, shooting video all the way, of how and when Robin used the computer. After analysis, the final 5 hours of video was edited to 20 minutes for conference viewing.

\section{Data analysis}

The immediacy of the diary indicates a complete involvement with the subject matter. An extract from the day he climbed Uluru (Ayer's Rock) reads:

Day 5 Wednesday 7th July Ayer's Rock-Olgas-Ayer's Rock

8.53 Would you believe that I am writing this half way up Ayer's Rock. Gotta go, I have to climb the rest of the way to the top and sign the HONOUR BOOK.

9.32 We have just reached the top point of Ayer's Rock and it is freezing up here with a chill factor of 2 . But we've done it we've at last reached the top of Ayer's Rock and I have to admit I am slightly proud of myself!!!

11.12am We got down at $10.27 \mathrm{am}$. Then went to the Ranger station, for morning tea and here we are having just had a cherry ripe and a bottle of Lift. I just found out that we were at the highest point which is $348 \mathrm{M}$ above sea level. 
$12.42 \mathrm{pm}$ We just left the Olgas and in my opinion they were not nearly as interesting as Ayer's Rock.

$7.57 \mathrm{pm}$ Went to bed early because I am very tired.

Note the indication that his self esteem is high in the line 'I am slightly proud of myself!!!'. As each day progressed, Robin could see his diary growing. He spent time writing on the bus, waiting for meals, on the top of Ayer's Rock and wherever he happened to be at the time. It was the first time he had experienced spontaneous writing in this fashion.

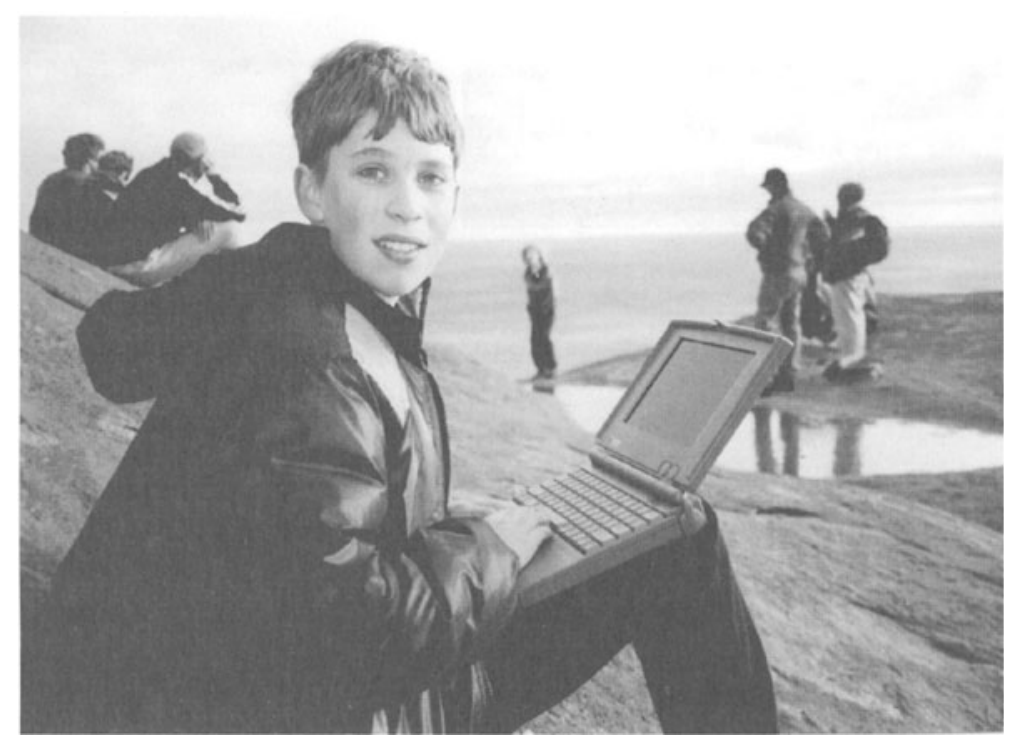

Fig. 2 On to of Uluru (Ayer's Rock)

Robin used the computer for diary writing (Fig. 2), formulating the database and account keeping. He also used it to read Hitch-hiker's Guide to the Galaxy and play games (Kings Bounty, Cannon Fodder) during the long hours on the bus, and sometimes during the evenings. He also read print books and magazines (Last of the Californian Girls, Moonrunner, Footrot Flats).

When Robin arrived home, the written part of his assignment was complete. All he had to do was print the files, choose illustrations and assemble all the material together into a folder. This was the first time he had completed such a long project. 
The mark he was awarded for the project was $100 \%$ with 5 bonus points on top. Part of the teacher's comment read:

"...The text is not as long as some, but it is all authentic and all given the right geographical emphasis. I like the sense of immediacy given by the laptop diary format...'.

This was the first time Robin had achieved this level of success. He was thrilled with his achievement, both the marks gained, and the satisfaction of completing such a seemingly daunting task.

Table 1 Comparison of Examination marks 1993/4

\begin{tabular}{lcccc}
\hline Subject & Mid 1993 & End 1993 & Mid 1994 & End 1994 \\
\hline English & 82 & 79 & 89 & 71 \\
Science & 79 & 76 & 86 & 91 \\
RE & 59 & 62 & 82 & 80 \\
German & 83 & 73 & 77 & 67 \\
Geography & 62 & 82 & 65 & 75 \\
History & 76 & 49 & 65 & 88 \\
Maths & 59 & 89 & 65 & 78 \\
\hline Totals & 500 & 510 & 529 & 550 \\
\hline
\end{tabular}

Comparing the Year 7 examination marks with the mid-year report card in Year 8 , it can be seen that Robin indeed made gains in most areas (Table. 1). The comparison shows a steady improvement.

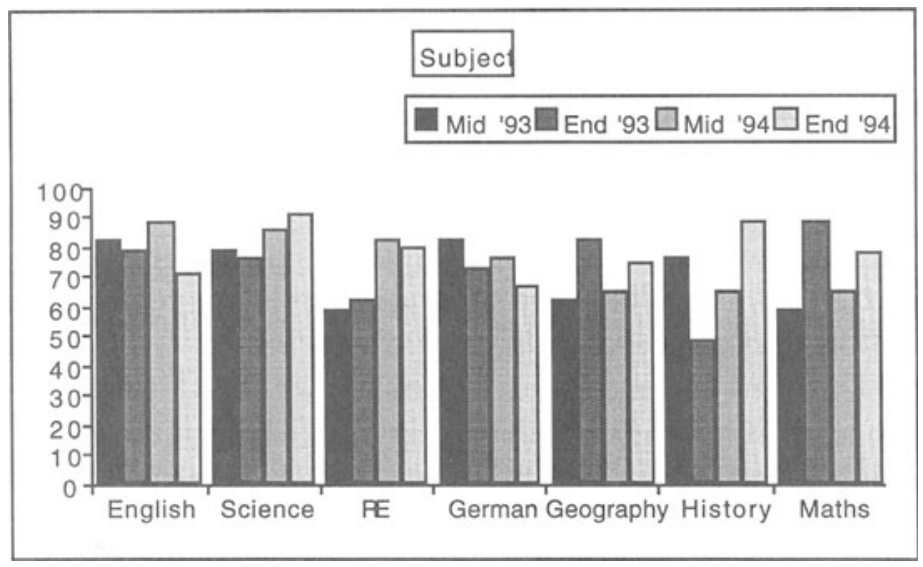

Fig. 3 Graph of examination marks over two years 
His geography mark was higher at the end of 1993 than mid-year 1994, perhaps due to a strong ripple effect from the success of his assignment. His maths was also higher at the end of Year 7, possibly for the same reason. Overall, however, it can be seen that his scores have improved steadily (Fig. 3).

His teachers' comments from one year to the next are also revealing (Table 2 ), and indicate that they are pleased with his progress.

Table 2 Teachers' comments over two years

\begin{tabular}{lll}
\hline Subject & Year & Comment \\
\hline Science & $9 / 6 / 93$ & Robin has learnt to solve problems rather than looking for excuses \\
& $3 / 12 / 93$ & $\begin{array}{l}\text { Robin has enjoyed and prospered in Science. These are good results } \\
\text { Robin has been extremely motivated and as a result has had much success. }\end{array}$ \\
& $8 / 6 / 94$ & $\begin{array}{l}\text { Excellent } \\
\text { Robin has a real flair for Science. Relevant and thoughtful questioning makes him } \\
\text { a pleasure to teach. }\end{array}$ \\
& $2 / 12 / 94$ & Robin must aim higher to realise his full potential \\
Geography & $9 / 6 / 93$ & Robin's superlative project has turned the tide \\
& $3 / 12 / 93$ & An interested and perceptive student \\
& $8 / 6 / 94$ & A very pleasing result from a capable student. \\
History & $2 / 12 / 94$ & Satisfactory but capable of improvement \\
& $9 / 6 / 93$ & Robin has shown little enthusiasm and has produced assignments of poor quality \\
& $3 / 12 / 93$ & Good attitude, but Robin's work and study methods need improvement \\
& $8 / 6 / 94$ & Robin has worked well, but he must get more organised in class. \\
RE & $2 / 12 / 94$ & With continued and consistent effort Robin's results should improve \\
& $9 / 6 / 93$ & Robin's exam results were surprisingly better than expected \\
& $3 / 12 / 93$ & Robin is producing sound results with a minimum of effort \\
& $8 / 6 / 94$ & Pleasing effort. Robin has made consistent progress. \\
\hline
\end{tabular}

\section{DISCUSSION}

Having rarely written more than half a page of text, a writing task such as this appeared very daunting for Robin. He would never have written such a lengthy, high quality document if he had to write longhand, cursive or noncursive. If he had written it by hand, the project would have been minimal, even incomplete, and the task performed reluctantly. Using the computer, as suggested by Piper [2] allowed him to hand in a well crafted piece of work.

The portable computer, which was not heavy or bulky, allowed him to take advantage of modern technology: it allowed him to write when and where he was, as his thoughts arose. This spontaneous activity was very motivating for him and allowed him to extend himself past his usual limits. This very empowering experience spurred him on to continue writing, and as the more he wrote, the more confident he became. His confidence grew as his work progressed, to the point where he easily completed the task.

Computers and other interactive technologies are most powerfully used where children are engaged in tasks with real purpose, as was the case with Robin. The importance of having a meaningful project to work with which 
was relevant to his experience, and which had a real purpose, all contributed to the success of the venture.

Certainly it must be taken into account that maturity may well have also contributed to an increase in self esteem and achievement. However, after years of underachieving, at last Robin proved to himself and others that he was capable of achieving real success. The role of the portable computer in this success cannot be denied.

From the time he was awarded the high grade for the project, Robin's school performance has steadily improved. He is now showing increased academic achievement, and even shining achievement in some areas. To his delight, he came top of the class in Science in the mid-year examinations in June 1994 and top of the class in Science and Commerce at the end of 1994.

Out of school, Robin continues to do his homework on a computer whenever he can. He has made several friends with whom he spends time in the playground and at home on weekends. He is developing into a good tennis player and learning to be part of a team with the local tennis club. The trip to Outback $\mathrm{Oz}$ and the subsequent success has had far-reaching effects, indeed liberating this learner!

\section{REFERENCES}

1. Alchin, G. (1993) Increasing self esteem and creativity of people with a developmental disability through the use of computer technology, in Australian Educational Computing 8, Special Conference Edition, July 1993.

2. Piper, D. (1989) Special tools for special kids. Hands on, Proceedings of the 7th Annual Conference NSW Computer Education Group (ed Sutton, D), Cheltenham, NSW.

3. Morocco, C. et al. (1985) Teaching children to write with computers: comparing approaches. The Writing Project, Technical Report No 1. Education Development Centre, Inc., Newton, Mass.

4. Computer Education Unit. (1987) Writing and computers. Erskineville, NSW, NSW Department of Education.

5. Pendreigh, B. (1990) Computers and genre: a pedagogy of empowerment. Computers in Education, Proceedings of the IFIP TC Fifth World Conference on Computers in Education-WCCE 90 (eds McDougall, A and Dowling, C), Amsterdam, Elsevier Science Publishers. 
6. Shand, C. (1992) Teaching writing in secondary schools - an approach. Kids, Curriculum, Computers and..., Proceedings of the 9th Annual Conference of the NSW Computer Education Group, (eds Wawrzyniak, S. and Samootin, L.) Sydney, NSW Computer Education Group.

7. Brown, D. and DeRusha, E. (1989) Unpanned gold: a 4 year secondary program designed to direct learning disabled students to achieve fullest potential in furthering education. Paper presented at the Annual Council for Exceptional Children, 67th, San Fran cisco, CA, April 1989.

8. Lang, S. \& Teifel, P.(1989) Operation Success 1989. Paper presented at the American Vocational Association Convention. Orlando, Florida, December 1989.

9. Gore, K. (1991) Computers and thinking skills: the HOTS program (DISCovery). Language Arts 8 (2).

10. Heger, H. (1992) Retaining Hispanic youth in school: an evaluation of a counselling based alternative school program. University of Texas at El Paso, College of Education, El Paso, Texas. Paper presented at the Annual Conference of the Rocky Mountain Educational Research Association. Stillwater, OK, October 1992.

11. Henry, Robyn. (1989) Report on Robin X. Wahroonga, NSW, Australia.

12. Henry, Robyn. (1991) Report on Robin X. Wahroonga, NSW, Australia. 